\title{
Efficiency, Exchange, and Auction: Philosophic Aspects of the Economic Approach to Law*
}

\author{
Jules L. Coleman $\dagger$
}

Conversational literacy in neoclassical welfare cconornics is an apparent prerequisite to gainful employment in American law schools. Loose talk of efficiency, cost-1ninimization, and the liability rule/property rule distmction punctuates faculty lounge discussions. There is simply no denying that the new law and economics has arrivcd. So it is a fond (if only temporary) farewell to Rawls and Nozick, and a warm welcome to Coase, Pigou, Calabresi, and Posner.

The new law and economics is not without critics, however. There is a growing hiterature which represents the view that law and cconornics ought to be relegated to a suitable place in the history of intellectual fads-the sooner, the better. Much of what has been written against law and economics, however, is based on unsympathetic, msensitive, and largely superficial understandings of the central works in the field. Unfortunately, much of what is written in the name of law and economics is equally insensitive to the limits within which economic analysis might prove fruitful. As unsound criticisms and unwarranted extensions of the economic approach to law mount, the time appears ripe for an examination of its analytic framework.

Three distinct but related activities fall witlim the domain of law and economics: two of these are analytic in nature, one is normative. Analytic law and economics may be either descriptive or positive. Descriptive law and economics is concerned with the principle of economic efficiency as an explanatory tool by which existing legal rules and decisions may be rationalized or comprehended. Richard Posner's

* An earlier version of this Article was entitled "The Philosophic Foundations of the Economic Approach to Law: Coase, Kaldor-Hicks and the Auctioning of Entitlements," and was cited accordingly. The author received numerous helpful comments on preliminary drafts. So useful were the comments that by incorporating them into the final draft, it was no longer clear to the author that he was working on the same paper. Consequently, the name has been changed to refiect more accurately the paper's content and to protect this piece from unwarranted association with prior drafts. The author would like to acknowledge his debt to Julius $O$. Sensat, Jan Vetter, George Fletcher, Guido Calabresi, and especially William Holahan for their helpful comments.

$\dagger$ Associate Professor of Philosophy, the University of Wisconsin-Milwaukee. Ph.D. 1972, The Rockefeller University; M.S.L. 1976, Yale Law School. 
A Theory of Negligence ${ }^{1}$ is characteristic of this approach. In his essay, Posner attempts to show that a large number of neghigence cases were decided along economic efficiency limes. His view is not that judges articulated and imvariably apphed an economic standard of adjudication. Instead, he claims that these cases may be rationahized or reconstructed in light of an economic theory of adjudication.

Positive law and economics is concerned less with the actual explanatory power of economic efficiency than it is with the capacity of market models to provide a conceptual apparatus within which traditional legal problems may be conceived. Typical is Isaac Ehrlich's work on crime. ${ }^{2}$ Ehrlich presents the imterplay between crime, crimmals, criminal law, and victims im market terms. Criminals are viewed as engaged in an economic activity-i.e., committing crimesand the criminal law and the rules and strategies governing its enforcement are thought of as the medium through which consumers-i.e., possible victims of crime-express their decisions about how much crime they are willing to accept at various prevention prices.

Normative law and economics is the home of reformers. Existing legal rules are evaluated and new ones fashioned in terms of their economic efficiency. Guido Calabresi's The Costs of Accidents $^{3}$ is an exemplary text in normative law and economics. It sets out and evaluates alternative systems of accident law according to the capacity of each to minimize the suin of the costs of accidents and the costs of avoiding thein.

Whether the new law and economics is restricted to model theoretic applications or whether instead it is advanced as an explanatory or normative discipline, its central organizing idea is that of economic effciency. The concept of economic efficiency, however, is complex and widely misunderstood. There are three or perhaps four notions of efficiency it coinprehends-allocative efficiency, Pareto optimality, Pareto superiority, and Kaldor-Hicks efficiency. ${ }^{4}$ Inadequate understanding of the diversity of these concepts surfaces im both imapt apphications and unfounded criticisms of the economic approach to law. Distinguishing the good from the bad in law and economics requires a deeper

1. Posner, A Theory of Negligence, 1 J. LEGal STUD. 29 (1972).

2. Ehrlich, The Deterrent Effect of Criminal Law Enforcment, 1 J. LEGAL SruD. 259 (1972).

3. G. Calabresi, The Costs of Accidents: A Legal and Economic Analysis (1970).

4. Even this list of efficiency notions is incomplete. Yet another efficiency standard has been advanced, such that an efficient distribution of resources is wealth optimizing. Posner, Utilitarianism, Economics, and Legal Theory, 8 J. LEGAL SruD. 103 (1979). Moreover, the notion of allocative efficiency, which is here employed in externality problems only, has a wider and ambiguous usage in broader microeconomic contexts. Posner's novel conception of efficiency is discussed in J. Coleman, Efficiency, Utility, and Wealth Maximization (forthcoming in the Hofstra Law Review). 
appreciation of the relationships among these notions of efficiency than has marked the literature to this point. The purpose of this Article is to provide at least the beginnings of such an understanding. Part I discusses Coase's theorem and the concept of allocative efficiency. Part II defines Pareto optimality and superiority and considers an argument that Coase's theorem is not about efficiency in the Paretian sense. Part III briefly discusses Coasian and Pigouvian approaches to externalities. Part IV discusses Richard Posner's "auction rule" for assigning entitleinents where bargains cannot be struck and explores its relationship to Paretian and Kaldor-Hicks notions of efficiency. Part V raises doubts about the adequacy of Posner's property right assigninent rule as a duplication of the essential aspects of Coase's theorem. The essay concludes with some brief remarks about the force of efficiency arguments in matters of public policy.

\section{CoAse's Theorem and Allocative EFficiency}

One way of stating Coase's theorem ${ }^{5}$-the one that is thought to have the most relevance to law and economics-is: given traditional assumptions of substantial knowledge, ${ }^{6}$ perfect rationality, and the absence of both transaction costs and income effects, ${ }^{7}$ the assignment of legal entitlements in cases of two-party incompatible land uses will be neutral as to the goal of allocative efficiency. A simple example best develops this insight.

Suppose that a rancher and a farmer own adjacent plots of land. The rancher raises cows on his land, while the farmer plants corn on his. Suppose as well that at the present time the rancher raises only one cow. He wants to raise a second cow. The farmer is opposed to this, however, because a roaming second cow will cause additional crop dainage. Coase demonstrates that the initial assignment of relevant property rights does not determine whether tlie second (or additional) cow is actually raised, provided that the rights are divisible and transferable.

To see this, let us suppose that the value of the second cow to the ranclier is $\$ 50$. This figure represents his gain (proflt) from raising a

5. The theorem is developed in Coase, The Problem of Social Cost, 3 J. L. \& EcoN. 1 (1960).

6. Commentators often assert that the Coase theorem requires that parties to the negotiations have perfect knowledge. This assumption trivializes the theorem and is stronger than necessary. One need assume only that the relevant parties have substantial relevant information. Additional pertinent information is revealed once actual negotiations are underway.

7. Bids are free from income effects when they do not reflect relative wealth. The consequences of income effects on efforts to employ the Coase theorem as a basis for assigning entitlements are discussed summarily in Part II infra. 
second cow. The cost imposed on the farmer by the second cow is the market value of the crop damage caused by that cow. The crop damage may be greater than, equal to, or less than the value of the second cow. Consider two cases. In one, the value of the anticipated crop dainage is, say, $\$ 25$; in the other, it is $\$ 75$.

The rancher will raise an additional cow in the first case; he will not in the second. These results are independent of the initial assignment of entitlements. In the first case, if the state assigns the farmer the right to prohibit a second cow, the parties will reach an agreement whereby the farmer will permit the rancher to raise a second cow, in return for which the rancher will compensate the farmer for any crop damage the second cow causes (plus whatever surplus the farmer's negotiation skills bring him). Provided they are able to negotiate with each other, the farmer is willing to sell his right to prohibit a second cow for at least $\$ 25$ and the rancher is willing to purchase it for as much as $\$ 50$. Under these conditions, rational persons will reach an accord that will entitle the rancher to a second cow.

If, in the first case, however, the state assigns the entitlement to the rancher straiglitaway, no transaction will occur. The farmer will be unwilling to purchase the right to prohibit the second cow for any more than the value of the crop damage, i.e., $\$ 25$. The rancher, on the other land, will be unwilling to part with his entitlement for less than the value of the second cow to him, i.e., $\$ 50$. When the marginal value of the second cow exceeds the marginal value of the anticipated crop dainage, the rancher will raise a second cow. This result occurs regardless of the initial assignment of entitlements.

In the second case-in which the marginal value of the anticipated crop damage exceeds the marginal value of the second cow-the additional cow will not be raised. If the state assigns to the rancher the riglit to raise a second cow, the farmer and the rancher will reach an accord in which the farmer, in excliange for the right to prohibit a second cow, will pay the ranclier an annount greater than or equal to the value of the cow to the rancher, i.e., $\$ 50$, and less than or equal to the value of the farmer's anticipated crop damage, i.e., $\$ 75$. If, however, the state assigns to the farmer the right to prohibit a second cow, no transaction will occur. The rancher will be unwilling to offer more than $\$ 50$; the farmer will be unwilling to accept less than $\$ 75$. Thus, regardless of the initial assignment of entitlements, the rancher will not raise a second cow in this case.

The primary lesson of Coase's example is that whether or not there will be a second, third, fourth, or $n$th cow does not depend on the initial assignment of property riglits. Instead, the number of cows raised and amount of corn grown is determined by the intersection of the rele- 
vant marginal profit (of ranching cows) and margmal damage (to corn) curves. The particular marginal profit and damage curves depend im turn on the relative market values of cows and corn. The farmer and the rancher will negotiate and trade until it is no longer beneficial (profitable) for either (or both) to trade further. The point at which bargaining ceases represents an efficient allocation of cows and corn. There, the resources are put to their most productive use. This point is represented by the intersection of the marginal profit and damage curves. ${ }^{8}$

Coase's theorem is not an empirical claim but is instead an analytic truth about what it means, under certain conditions, to act rationally. In the circumstances suggested by the rancher/farmer example, to act rationally is to maximize productive resource use. Rationahty requires of the incompatible landusers that they behave "as a firm" with two productive interests. The question before the "firm" is how to use the land to maximize its productive output or profit. The answer to that question, above all else, depends on the market values of resources, not on the assignment of property rights. To act rationally, then, is to promote allocative efficiency, which, $\mathrm{m}$ cases of this sort, is to put resources to their profit-maximizimg use.

Although the assignment of entitlements is neutral as to the pursuit of optimal resource use, it is not neutral with respect to the distribution of wealth between competing landusers. If the value of the second cow exceeds the value of anticipated crop damage, then the assignment of the property right to either party will have no impact on the rancher's raising a second cow. If the state assigns the entitlement to the farıner, however, he will sell it for at least $\$ 25$ to the rancher, thus increasing his wealth by that sum. If the state assigns the right to the rancher, his wealth will mcrease by the right's market value. Similarly, the assignment of entitlements will affect the parties' relative wealth in the case in which the value of the anticipated crop damage exceeds the value of the second cow.

The traditional understanding of Coase's theorem might be summarized as follows: allocative efficiency, or the maximuin productive use of resources, does not depend on the initial assignment of entitlements. The initial assignment is only the starting point from which negotiations begin. The point at which negotiations cease represents the efficient allocation of resources. The initial assignment of entitlements, however, does affect the relative wealth of the competimg parties siniply because the assignment determines which party has to do the purchasing (or what economists misleadingly call "bribing").

8. For a graphic demonstration of this point, see Part III infra, in which Coasian and Pigouvian approaches to externalities are contrasted. 
Economists differ about whether Coase's theorem can be extended to cover inore complex cases involving multiparty transactions, ${ }^{9}$ and about whether it holds in the short run only, i.e., whether the efficient result is unique. ${ }^{10}$ This paper will ignore those complications and focus instead on related unatters pertaining to the hmits within which the theorem may be legitimately extended. The first question concerns the relationship between the concept of allocational efficiency explored by Coase and the Paretian standards of efficiency employed in recent works about law and economics.

\section{II}

\section{Pareto Optimality and Allocative Efficiency}

Any discussion of Pareto efficiency must begin with definitions of Pareto optimality, Pareto superiority, and Pareto inferiority. To claim that resources or goods are allocated in a Pareto optimal fashion is to maintain that any further reallocation of resources will benefit one person only at the expense of another. An allocation of resources is Pareto superior to an alternative allocation if and only if no person is disadvantaged by it and the lot of at least one person is improved. An allocation of resources is Pareto inferior to another if there is a distribution Pareto superior to it. The concepts of Pareto superiority and optimality are analytically connected in the following way: a Pareto optimal distribution has no distributions Pareto superior to it.

Robert Nozick draws an important and useful distinction between "patterned" and "historical" allocation principles." The distinguishing feature of patterned principles of allocation is that they evaluate existing distributions of wealth-what people have at any given moinent in history-without considering the manner and history of acquisition. In contrast, a historical standard of evaluation emphasizes the manner in which people come to what they have, and thereby rejects the plausibility of evaluating allocations purely against a history-neutral standard. Historical standards for evaluating allocations require that a story be told. Certain story lines are defensible; others are not. In any event, the given end-state is normatively unnnportant independent of the manner in which it was reached.

Nozick's distinction may be transposed to discussions of Pareto efficiency. ${ }^{12}$ The "patterned aspect" of Pareto efficiency is captured by

9. Frech, The Extended Coase Theorem and Long Run Equilibrium, 17 ECON. INQUIRY 254 (1979).

10. Id.

11. R. Nozick, ANaRchy, State AND Utopia (1974).

12. Nozick would be rightly suspicious of any effort to transpose his distinction in this manner unless it were made clear that he rejects the entirety of the economic approach to law. That is 
the idea of Pareto optimahty. The "historical aspect" of Pareto efficiency is loosely captured by the idea of Pareto superiority. This distinction is easily understood. A Pareto optimal distribution can be reached either by Pareto superior steps or "moves," by Pareto inferior noves, or by a combination of the two. Saying that a distribution is Pareto efficient, therefore, may call attention to the efficiency of the existing distribution regardless of the efficiency of the steps along the way to it. In contrast, however, labeling a distribution Pareto efficient might nnean not only that the existing distribution is Pareto optimal, but also that it is the result only of Pareto superior (and efficient in that sense) moves.

In The Problem of Social Cost, Coase never exphcitly uses Paretian notions of efficiency. He talks only about allocative and allocational efficiency. One argument recently proposed by George Fletcher denies that there is an analytic relationship between Paretian and allocative efficiency. Fletcher's argument is interesting for the following reason. The new law and economics is wedded to the Paretian standard and at the same time identifies its roots in Coase (as well as in Pigou). If Fletcher is right, then, much of the new law and economics derives from an unwarranted extension of Coase's theorem. In short, if Fletcher is right, the new law and economics may simply rest on a inistake. He writes:

The leap of faith by the new school of law and economics is that bargains say, between smokers and nonsmokers are just like the problem of allocative efficiency between the rancher and the farmer. But there are two critical reasons that render this leap of faith but an embrace of the unknown. ${ }^{13}$

The crucial difference, according to Fletcher, is that in the rancher/farmer case, the rancher and the farmer bid against one another on the basis of estabhshed prices. This is significant for Fletcher because "it implies that the Coasian standard of allocative efficiency is immune to the distribution of income between farmer and rancher." 14 In contrast, the bargains struck between sinokers and nonsinokers express their subjective preferences and are a function of their relative wealth. So the efficiency that results in the allocation of resources be-

because the economic approach justifies intervening in free inarket exchanges if the exchanges are inefficient. Nozick, of course, would reject economic "interventionism" as a violation of autonomy and as an illegitimate extension of the state's coercive powers. Moreover, the distinction he draws between "patterned" and "historical" principles is employed for the sole purpose of providing criteria by which the legitinacy of current right claims may be assessed. There is no deep analogy between his arguments and the economic ones. Still, the distinction he draws is an important one which is useful in analyzing different aspects of the Paretian efficiency notions.

13. G. Fletcher, Law and Economics (unpublished manuscript).

14. Id. 
tween crops and cows is different from the efficiency that results in the resource allocation between smokers and nonsmokers.

It is more fruitful to put this observation in a nore technical fashion before considering its force. Suppose that the rancher/farmer and smoker/nonsinoker exainples are understood to be providing definitions of rationality. The definition of rationality expressed in Coase's rancher/farmer exainple seeins to be: to act rationally is to maxinize profits through optimal use of productive resources. The definition of rationahity the smoker/nonsinoker exainple generates is this: to act rationally is to inaximize utility or welfare through the satisfaction of one's preferences.

For Fletcher's argument to count against the new law and economics, the definition of rationality coinprehended by the cases of the smoker/nonsmoker variety would have to be an inappropriate extension of the definition of rationality comprehended by the rancher/fariner example. But it is not. Both Coase's example and the smoker/nonsmoker example express the general principle that to act rationally is to inaximize individual utility. In Coase's rancher/farmer example, the relevant preference is profit inaximization, and pursuing it obviously depends on market prices; the rancher's and the farmer's utility functions depend on the inarket prices of beef, grain, and the like as well as on their wealth. Notably, nothing Coase says hangs on the fact that what the farmer and the rancher are willing to bid is a function of their interest in maximizing profit. The arguinent will work just as well if the farmer, for exainple, were willing to pay an additional ten dollars beyond the inarket price of the anticipated corn damage just to avoid having another "ugly" cow in the neighborhood. In such a case his utility is a function both of his desire to profit and to live in an aesthetically pleasing environment.

Coase's example, then, is simiply a special case of the general utility argument in which maximizing utility is extensionally equivalent to maximizing profit. It is a peculiar feature of Coase's example-which admittedly is not present in cases mvolving, for exanple, aesthetic preferences-that in seeking to maximize their respective welfare, both the farmer and the rancher insure that the resources are put to their profitmaximizing use.

The argument against extending Coase's theorein to cases involving subjective preferences is based on an inadequate understanding of an important dimension of Coase's paper. Coase was trying to argue not only that the assignment of entitlements between, say, ranchers and fariners would be irrelevant to the efficiency of the ultimate allocation of cows and corn, but also that the resulting efficient allocation would be unique; and that its uniqueness could not be upset over the long run. 
Indeed, it is the uniqueness claim that is particularly novel and controversial. To argue for the uniqueness of the efficient allocation of cows and corn, Coase's proof assumes that the economy is perfectly competitive, that the prices of goods are set outside the context of the externality problem and, as it were, given to the rancher and the farmer (the partial equilibrium model), and that the bargams struck between the rancher and the farmer are not affected by their relative incomes, i.e., their exchanges do not exhibit "inconie effects." That the farmer and the rancher bid against one another on the basis of established prices, then, is merely a constraint imposed on the argument in order to generate the uniqueness result. It is not relevant to the claim that the result of their exchanges will be efficient in either the allocational or Paretian sense. Whether the absence of income effects constraint in conjunction with other assumptions of the arguinent suffices to establish uniqueness remains a matter of some controversy. ${ }^{15}$

Fletcher advances another intriguing argument against a Paretian interpretation of Coase's theorem. This arguinent requires reconsidering the rancher/farmer example. Consider the case in which the unarginal value of the second cow exceeds the marginal value of the anticipated damage to the corn. In this case, the rancher will raise a second cow. Is his doing so, however, Pareto efficient? Fletcher is not convinced that it is. He argues quite simply that if the rancher raises a second cow, the farmer will be disadvantaged by an amount equal to the damage the cow will cause him. The rancher's raising a second cow, then, is Pareto efficient, in Fletcher's view, only if the rancher compensates the farmer for the damage the second cow causes. In the absence of compensation, raising the second cow is not Pareto efficient because the farmer is inade worse off. So a distribution of resources which is allocatively efficient need not be Pareto efficient.

This argument is illuminating but mistaken. To see this, let us first depict the rancher/farmer exainple systeinatically:

Let $S_{1}$ be the situation in which one cow is ranched.

Let $S_{2}$ be the situation in which the state assigns to the farmer an entitlement to prohibit the second cow.

Let $S_{3}$ be the situation in which the state assigns to the rancher an entitlement to raise the second cow.

Let $S_{4}$ be the situation in which the rancher purchases the right to raise the second cow from the farmer.

Both $S_{3}$ and $S_{4}$ represent the allocatively efficient distribution of cows and corn. Fletcher contends that they are not both Pareto efficient. But they are. If the state assigns the entitlement to the farmer

15. See generally Coleman, supra note 4 . 
$\left(S_{2}\right)$, the situation is not Pareto optimal because there exists a redistribution Pareto superior to it $\left(S_{4}\right)$. That is, in $S_{4}$ the farmer is made no worse off because he is coinpensated for his loss and the rancher's lot is improved. $S_{4}$ is Pareto optimal; once it is reached no rearrangement of the resources can enhance the farmer without harming the rancher. For similar reasons, $S_{3}$ is also Pareto optimal; it is impossible to imagine a redistribution that would improve the farmer's position that would not also disadvantage the rancher. It follows, then, contrary to Fletcher, that Coase's theorem is about Pareto efficiency-because it is about Pareto optimality.

Although both $S_{3}$ and $S_{4}$ are Pareto optimal, they differ in an important respect. $S_{2}$ is Pareto superior to $S_{1}$, and $S_{4}$ is Pareto superior to both. In contrast, $S_{3}$ is not Pareto superior to $S_{1}$. That is because in $S_{3}$ the farmer is worse off than he was in $S_{1}$. He is going to lose whatever crops the second cow destroys without being compensated. Thus, society achieves a Pareto optimal outcome either im $S_{3}$ or $S_{4}$ but makes a Pareto inferior nnove in going from $S_{1}$ to $S_{3}$. In reaching $S_{4}$ through the intermediate step of $S_{2}$, on the other hand, each move to the optimal result is itself Pareto superior to the previous one.

Fletcher's claim that Coase's theorem is unrelated to Pareto efficiency because cases like $S_{3}$ make one party worse off than before thus rests on a confusion. Coase's theorem shows that regardless of the initial assignment of entitlements either $S_{3}$ or $S_{4}$ will result, both of which are Pareto optimal. $S_{3}$ and $S_{4}$ differ, however, with respect to $S_{1}$, in particular with respect to the relative well-being of the farmer. ${ }^{16}$

16. Some readers of previous drafts of this Article, including Fletcher, have questioncd whether assigning entitlements could ever be considered Pareto superior. These skeptics could mean one of two things: either that allocations that result from assigning entitlements are never in fact Pareto superior or that it is conceptually impossible to determine if they are. In the first case, the claim is that the proposition "assigning entitlements to $x$ is Pareto superior to the case in which no entitlements exist" is always false; in the second case, the claim is that the proposition is meaningless. Both of these claims are, I think, mistaken. The view that the relevant proposition is always false assumes that Pareto comparisons are at least meaningful. It would then be an empirical question whether in fact a particular assignment of entitlements was Pareto superior. And it is hard to imagine why, in the absence of empirical data pertinent to each case, one would confidently assert that the assignment could never be Pareto superior.

The more interesting claim is that it is conceptually impossible to compare an assignment of entitlements to a previous allocation. There are two arguments one might advance to support this claim, both of which are ultimately unconvincing. First, one could argue that as a matter of fact there never is a distribution of resources in which entitlements are not assigned. So the state never assigns entitlements; it merely either recognizes or reorganizes them. This claim is false. Moreover, it doesn't undermine the Pareto comparison. Alternatively, one could argue that assigning entitlements does not itself reallocate resources; it merely entitles people to act in certain ways. For example, if the rancher has one cow at $t$, and then is assigned the right to another cow at $t_{2}$, the distribution of resources need not change as long as the rancher chooses not to raise a second cow. So the distribution of resources need not be affected by the assignment of entitlements only. But this argument misses the point. Entitlements are themselves resources; in addition, the Pareto 
Coase's theorem and Fletcher's misunderstanding of it provide the perfect opportunity to emphasize the distimction I have drawn between Paretian efficiency in his historical and end-state aspects. Coase's theorem is about Pareto efficiency $\mathrm{m}$ its end-state or patterned dimension; it is about Pareto optimality. It is not necessarily about Pareto efficiency in its historical aspect; it is not about Pareto superiority. Coase's theorein implies that from the point of view of optimality society should be indifferent between $S_{3}$ and $S_{4}$. Economists sometimes argue that the reasons for preferring, for example, $S_{4}$ to $S_{3}$ have nothing to do with efficiency but with considerations of wealth distribution. This argument suggests that one relevant distinction between $S_{3}$ and $S_{4}$ has to do with Paretian notions of efficiency. $S_{4}$, but not $S_{3}$, involves only Pareto superior moves from $S_{1}$. Only $S_{4}$ is the result of "mutual gain through trade."

Coase's claim that, under conditions of rationahity, substantial knowledge, and zero transactions costs, the outcomes of trades will be efficient holds in cases of both the farmer/rancher and smoker/nonsmoker variety.

Still, there is this important distinction between Pareto and allocative efficiency. Resources that are distributed in a Pareto optimal fashion need not optimize wealth and, therefore, need not be allocationally efficient. A nonallocationally efficient but Pareto optimal distribution will occur whenever individuals' preferences are complex and include, for example, aesthetic as well as wealth-maximizing preferences. In short, because the rancher and the farmer in Coase's exainple are assuined to prefer only to inaximize wealth, the outcome of their trades will be both allocative and Pareto efficient. In real life an individual's preferences are presuinably inore profound. Consequently there is no guarantee that trades ainong such persons will be efficient in both senses. As long as the conditions of rationality, knowledge, and zero transactions costs are adequately satisfied, however, the outcoine of trades ainong thein will be Pareto optimal.

\section{III}

\section{CAusation AND EXTERNALITIES ${ }^{17}$}

The efficiency problem of concern to Coase arises from the existence of externahties. Externalities are a category of external effects. External effects are byproducts of an activity that influence the produc-

comparisons are made between welfare levels of persons. So the rancher is better off even if he does not ranch the second cow, merely because he now has the right to.

17. The arguments in this section summarize points developed in greater detail in Coleman, supra note 4. 
tion of other goods or the welfare (or utility) of other individuals. External effects therefore may be either beneficial or harinful. Externalities are inefficient external effects-social costs or benefits that result in inefficient production or nonoptimal distributions of welfare. ${ }^{18}$ To internatize an externality is to eliminate the inefficiency in production or exchange it generates. Internalization need not, and often does not, require that the external effect itself be eliminated.

The argument Coase develops in The Problem of Social Cost is primarily a response to the Pigouvian approach to externalities. Where Pigou argues that externalities ought to be controlled by taxes to internahize their social costs, Coase deinonstrates that under certain conditions the externality can be internalized by private exchanges between the individuals engaged in the externahity-causing activity and those harmed by it.

The differences between the Pigouvian and Coasian approaches to externalities as well as the important and widely misunderstood distinction between external effects and externalities is illustrated by the followimg graphic example:

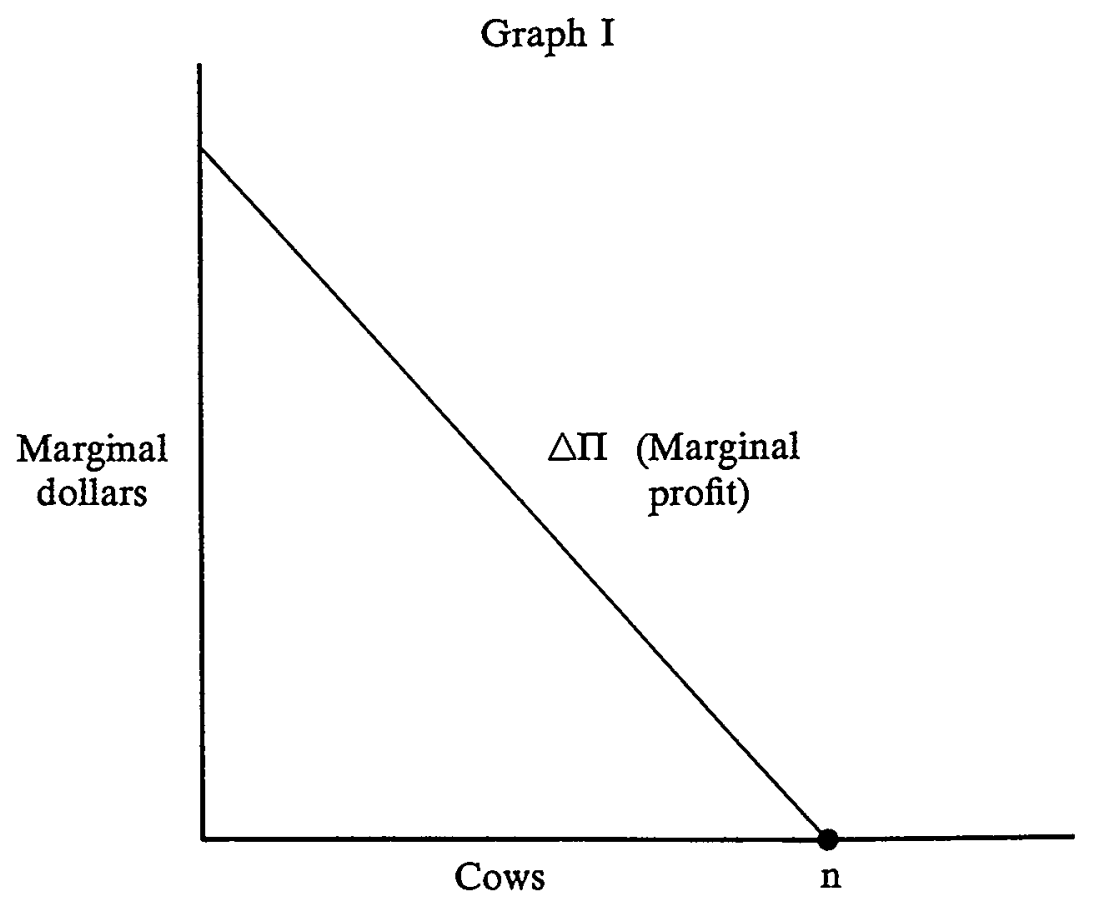

18. The distinction between externalities and external effects is widely misunderstood even in elementary economics texts. E.g., W. Nicholson, INTERMEdiate Microeconomics AND lTs Application (1975). 
Graph I represents the marginal profit of raising cows as a function of the number of cows raised. Raising cows continues, though marginal profit diminishes, until that point represented by $n$, at which marginal profit equals inargmal cost.

\section{Graph II}

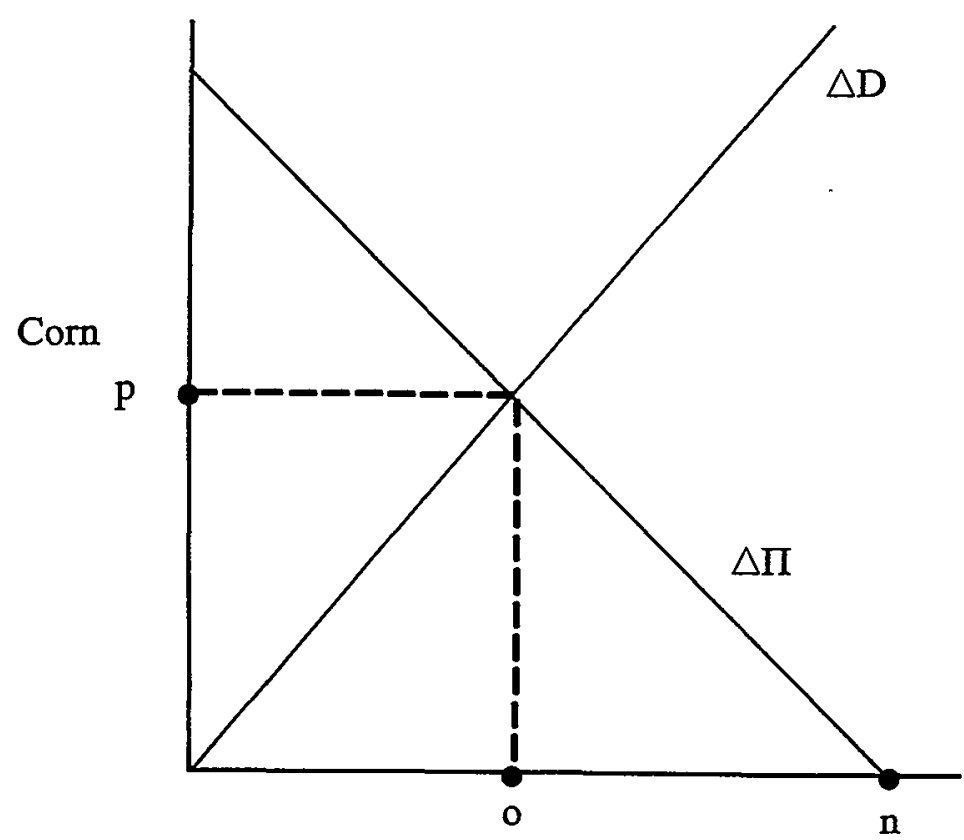

Cows

Graph II represents the marginal dainage to corn as a function of the number of cows ranched. Again, $n$ represents the number of cows that, in the absence of farming, the rancher would raise. The intersection of the marginal profit and dainage curves represents the efficient allocation of corn and cows. At that poimt, $o$ cows are ranched and $p$ corn is grown. When $o$ cows are ranched and $p$ corn is grown the distribution of resources is efficient in the sense discussed in Part I of this essay: that is, there is allocational efficiency.

Graph II also illustrates the distinction between an external effect and an externality. Every point to the right of the vertex represents an external effect of ranching on farming. Only points to the right of the intersection of the marginal profit and inarginal dainage curves, however, represent externalities of ranching on farming. All points to the left of the vertex constructed at $n$ constitute external effects of farining on ranching. This follows from the fact that in the absence of fencing, 
an increase in the corn crop requires a corresponding reduction in ranching. Put another way, a reduction in dainage to the corn crop requires a reduction in cows ranched which, in turn, means a reduction in the rancher's inarginal profit (a forgone benefit). Every point to the left of the intersection of the marginal profit and danage curves represents an externatity of farming on ranching.

To distinguish Pigou from Coase, suppose that the rancher is raising $n$ cows where $o$ would be optimal. The question is, how should society reduce the number of cows froin $n$ to $o$ ? According to Pigou, imposing a tax on ranching equal to the inarginal damage associated with each additional cow beyond $o$ would eliminate the marginal profit of ranching any more than $o$ cows. The rancher would then behave as if his marginal profit curve intersected the axis at $o$ rather than at $n$. That is because he will ranch up to that point at which inarginal profit equals marginal cost. The Pigouvian tax shifts that point from $n$ to 0 . This is illustrated in Graph III:

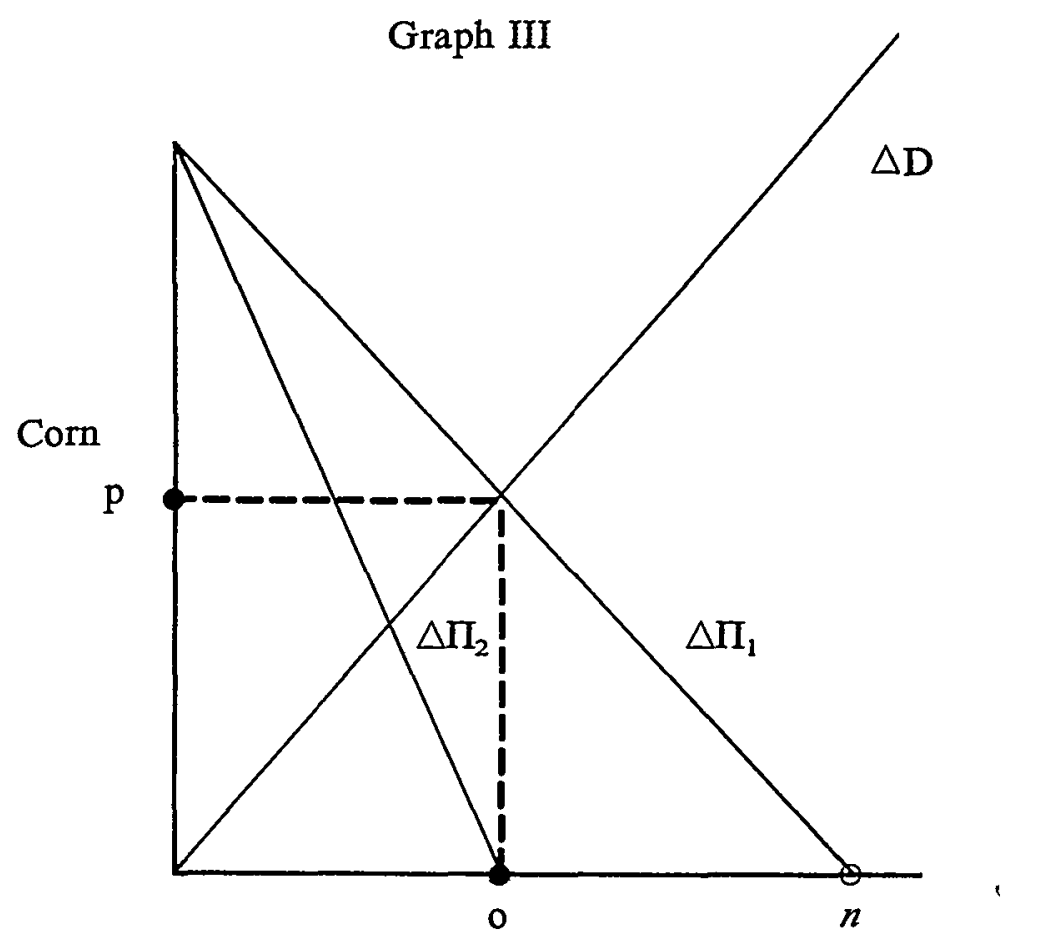

Cows

Coase rejects the Pigouvian approach to externalities. His attack is threefold. First, Coase takes issue with the causal basis of the Pigouvian analysis. Second, he argues (as Part I illustrated) that the 
optimal allocation may be secured through private exchange. Finally, he claims that as long as the parties are free to negotiate, the Pigouvian tax may lead to an mefficient allocation of resources.

The Pigouvian approach to externalities begins with the plausible imitial premise that the rancher's cows cause the farmer measurable damage: that, in general, certain activities cause harm to other activities. From his philosophically indubitable premise, the Pigouvians argue that as a ineans of internalizimg externalities the costs of the harms should be borne by those activities that cause them.

Coase, like his cohorts in contemporary law and economics, is skeptical about the existence of natural, in-the-world, nonreciprocal causal relations necessary to the Pigouvian approach. The ultimate reciprocity of causal relations, for Coase, is demonstrated by the following simple argument: if the rancher is permitted an additional cow, the farmer will be harmed. If, however, the farmer is entitled to prohibit the additional cow, the rancher will be harmed (i.e., he will be forced to forgo a benefit). The question, for Coase, therefore, is not which activity causes harm; instead, it is which harm society ought to allow.

The general Coasian position is that it is impossible to conceive of nonreciprocal causal relations in the absence of, or outside the context of, a set of entitlements. Only after we know who is entitled to what can we know who causes harm to whom. Further, because in the absence of entitlements causal language is mappropriate, we carmot employ alleged causal relations as the basis for assigning entitlements, or as a justification for imposing a tax burden.

Both Coase and the Pigouvians are confused in philosophically interestimg ways: the Pigouvians in believing that the imposition of a tax burden is justified by the existence of nonreciprocal causal relations; Coase in believing that the Pigouvian conclusion is not warranted because the premise from which it follows is false. In fact, Pigou is right in believing that such causal relations exist but wrong in assessing their justificatory import. Coase is right in questioning their normative sigmificance but wrong in denying their existence.

Coase's arguments agaimst the very existence of nonreciprocal causal relations is based on an obvious conceptual mistake. One does not have to know the assignment of property rights between ranchers and farmers or between pollutors and "pollutees" to know that roaming cows destroy (cause harm to) corn crops, or that pollution harms its victims. The harm cows cause crops is not offset by any reciprocal harm corn causes cows-provided, of course, the corn is not poisonous. It may be true that in prohibiting an additional cow or in restricting the pollutor society causes each a certain harm; or that in permitting an 
additional cow society causes the farmer harm. But the "harms" society causes by making one rather than another entitlement decision are conceptually different from the harms two coinpeting activities may or may not cause each other.

Like Pigou, certain critics of the economic approach to law, for example Richard Epstein, ${ }^{19}$ have made too much of the fact that nonreciprocal, in-the-world causal relations exist. It does not follow from the existence of such relations that liability or tax burdens may be justified on the basis of them. The justification for such burdens requires further controversial normative preinises. Proponents of law and economics are surely wrong in denying the existence of nonreciprocal causal relations. Still, this error does not necessarily undermine their deeper claims-at least not in this case. For we could understand Coase (and perhaps other proponents of law and econoinics) not as denying the existence of causal relations but as denying the relevance of such relations to securmg econornic efficiency. Put this way, the poimt of Coase's theorem is that if rationality, substantial knowledge, and zero transactions costs exist, identifying an activity as externality causing is irrelevant to securing efficiency. For if a market exists or can be established im which the relevant parties can each gain through trade, a point of optimal satisfaction will be reached, regardless of both the original assignment of entitleinents and the depths of our ignorance of the metaphysics of causal relations.

Coase's other important poimt is that as long as the parties are free to negotiate, a Pigouvian tax nnay lead to an inefficient result. This is illustrated in the following graph:

19. Epstein, A Theory of Strict Liability, 2 J. LEGAL STUD. 151 (1973). 


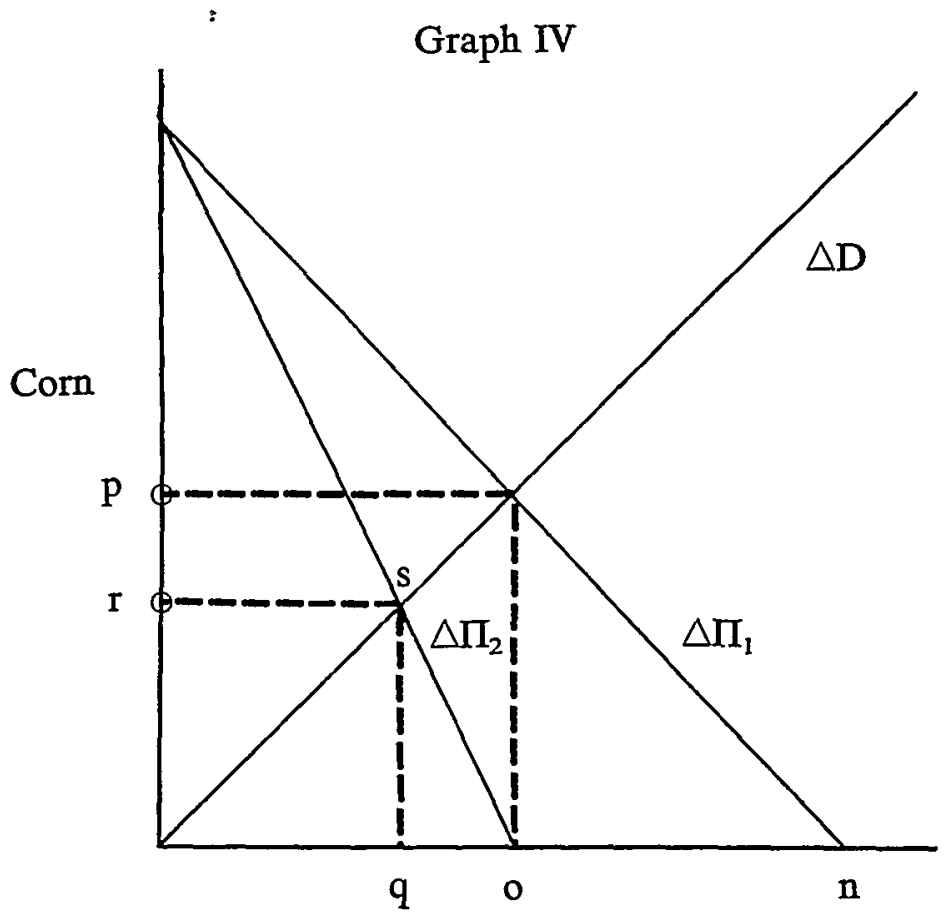

Cows

The Pigouvian tax reduces the number of cows to $o$ from $n$ and increases the amount of corn to $p$. The new marginal profit curve through $o$, however, intersects the marginal cost curve at $s$. Consequently, both the rancher and the farmer can gam through trade by negotiating with each other until $s$ is reached, thus reducing both corn and cow production. The result of their negotiations will be $q$ cows and $r$ corn, which by hypothesis is inefficient.

\section{IV}

\section{Pareto EFficiency, KaldoR-Hicks EFFICIENCY, AND Posner's Property Right AsSignMENT Rule}

Coase's theorem holds only where transaction costs are sufficiently imsignificant to allow the market to work its way to the efficient result through the process of mutual gain through trade. In many cases, however, the existence of transaction costs may make it impossible for the relevant parties to reach an accord that will increase their respective utilities. Consider, for example, the case in which the farmer is initially assigned the right to prohibit a second cow. If the cost of the transaction exceeds the difference between the value to the rancher of the second cow and the value to the farmer of the corn destroyed by that cow, 
the rancher will not purchase the right to a second cow from the farmer. For if it will cost the rancher $\$ 30$ in transaction costs to purchase the right from the farmer, he will be required to pay $\$ 55$ for what he values at $\$ 50$. Because no transaction occurs, the farmer maintains the entitlement though his domg so is mefficient; that is, there exists a redistribution Pareto superior to it. Failures of this sort are termed "market failures."

Where transaction costs create market failures, the mitial assignment of entitlements makes a difference from the point of view of efficiency. Consequently, the critical question concerns how externalities are to be imternalized (or controlled) when transaction or other costs threaten the adequacy of the market to promote efficiency through private exchange.

The recent hiterature indicates three approaches to the problem of controlling externalities when markets are inadequate to the task: taxes or subsidies, property rules, and liability rules. Each approach involves some sort of intervention in the market by a central (public) authority. The tax approach was discussed earlier. The fundamental idea is to tax on a per unit basis the inefficient output of the externality generating activity. The tax is set equal to the marginal damage associated with each nonefficient unit of ouput, thus promoting an efficient output by aggregatimg marginal social cost and margmal private cost. (The tax approach is often thought to be equivalent economically to a subsidy in which the firm is subsidized an appropriate amount for each unit of reduced inefficient output. ${ }^{20}$ )

The Pigouvian tax or subsidy may be contrasted with both the liability and property rule approaches. The latter approaches both involve two components for controlling externalities. Coinmon to both is the initial assignment of entitlements. The approaches differ, however, with respect to the instruments employed to protect the entitlement once assigned. Property rules protect entitlements by enablimg the right bearer to enjoin others from reducing the level of protection the entitlement affords him except as he may be willing to forgo it at a mutually acceptable "price." According to the liability rule, a nonentitled party may reduce the value of the entitlement without regard to the right holder's desires provided damages are paid. The amount of damages is set by a collective body, usually a court, and need not reflect what the entitled party would have been willing to accept for a reduction in the value of his entitlement. Liability rules give nonentitled parties the right to purchase at an objectively set price part or all of an entitlement

20. But cf. Polinsky, Notes on the Symmetry of Taxes and Subsidies in Pollution Control, 12 CANAdian J. Econ. 75 (1979) (subsidies may be assymetric and inefficient in both the long and short run compared to a tax). 
that is held by another. Property rules prohibit such takings in the absence of agreement between the relevant parties. ${ }^{21}$

In this paper I want to consider what is common to the property rule and liability rule approaclies, i.e., the assignment of entitlements. ${ }^{22}$ The problem of assigning entitlements arises because any number of costs (usually transaction and information costs) makes it impossible to internalize externalities through private exchange. Consequently the initial assignment of entitlements will affect the efficiency of the ultimate outcoines. The question then is by what primciple ought entitlements to be assigned.

To resolve this question Richard Posner offers the following assignment principle (A.P.):

A.P.: Confer the entitlement on that party who would have purchased it had the transaction costs not made it irrational for him to do so.

Simply put, A.P. confers entitlements on efficient uses. Another way to express this is that where markets cannot be used to secure efficiency, entitlements should be assigned to simulate or mimic the market by producing the results the market would have produced. The general primciple is to assign entitlements to mimic the market. ${ }^{23}$

This and the following section explore the relationship between the property right assigninent rule and both Coase's theorem and the concept of Kaldor-Hicks efficiency. My primary purpose is not to evaluate the property right assignment rule's success or failure but to develop its relationship to the work from which it allegedly derives.

A redistribution of resources is Kaldor-Hicks efficient if and only if under the redistribution the winners win enough so that they could compensate the losers. The notion of Kaldor-Hicks efficiency does not require that the winners actually compensate the losers. In effect, a redistribution is Kaldor-Hicks efficient if and only if it is a "possible" Pareto superior redistribution.

Kaldor-Hicks efficient distributions do not in general map onto Pareto superior distributions. The failure to require compensation may have the effect of producing losers; the requirements of Pareto superiority are thus not satisfied. In general, a distribution that is Kaldor-Hicks efficient need not be Pareto optimal either. If a distribution is Kaldor-

21. The liability rule/property rule distinction is traced to the important paper by Calabresi \& Melamed, Property Rules, Liability Rules, and Inalienability: One View of the Cathedral, 85 HARV. L. REV. 1089 (1972).

22. Economists are more often concerned with the question of how entitlements are to be protected once assigned than with the question of how they are to be assigned. See generally Polinsky, Controlling Externalities and Protecting Entitlements: Property Right, Liability Rule, and Tax Subsidy Approaches, 8 J. Legal STud. 1 (1979).

23. R. POSNER, ECONOMIC ANALysis of LAW (1972). 
Hicks efficient then the position of the winners has been improved more than the position of the losers has been worsened. It does not follow that from their new relative positions the winners and losers are incapable of further mutual improvement through trade. Thus, a Kaldor-Hicks efficient allocation need be neither Pareto superior nor Pareto optimal, though it may be either or both. In addition, KaldorHicks efficiency has the property that if the parties are already at a Pareto optimal point applying Kaldor-Hicks efficiency will not produce a non-Pareto optimal distribution. The formal way of putting this point is: Kaldor-Hicks efficiency will not lead away from the "contract curve." If the parties are not already on the contract curve, however, applying the Kaldor-Hicks formula will not insure that they will find it. The differences between the concepts of Pareto optimahity, Pareto superiority, and Kaldor-Hicks efficiency are usefully illustrated by the following Edgeworth-Bowley Box:

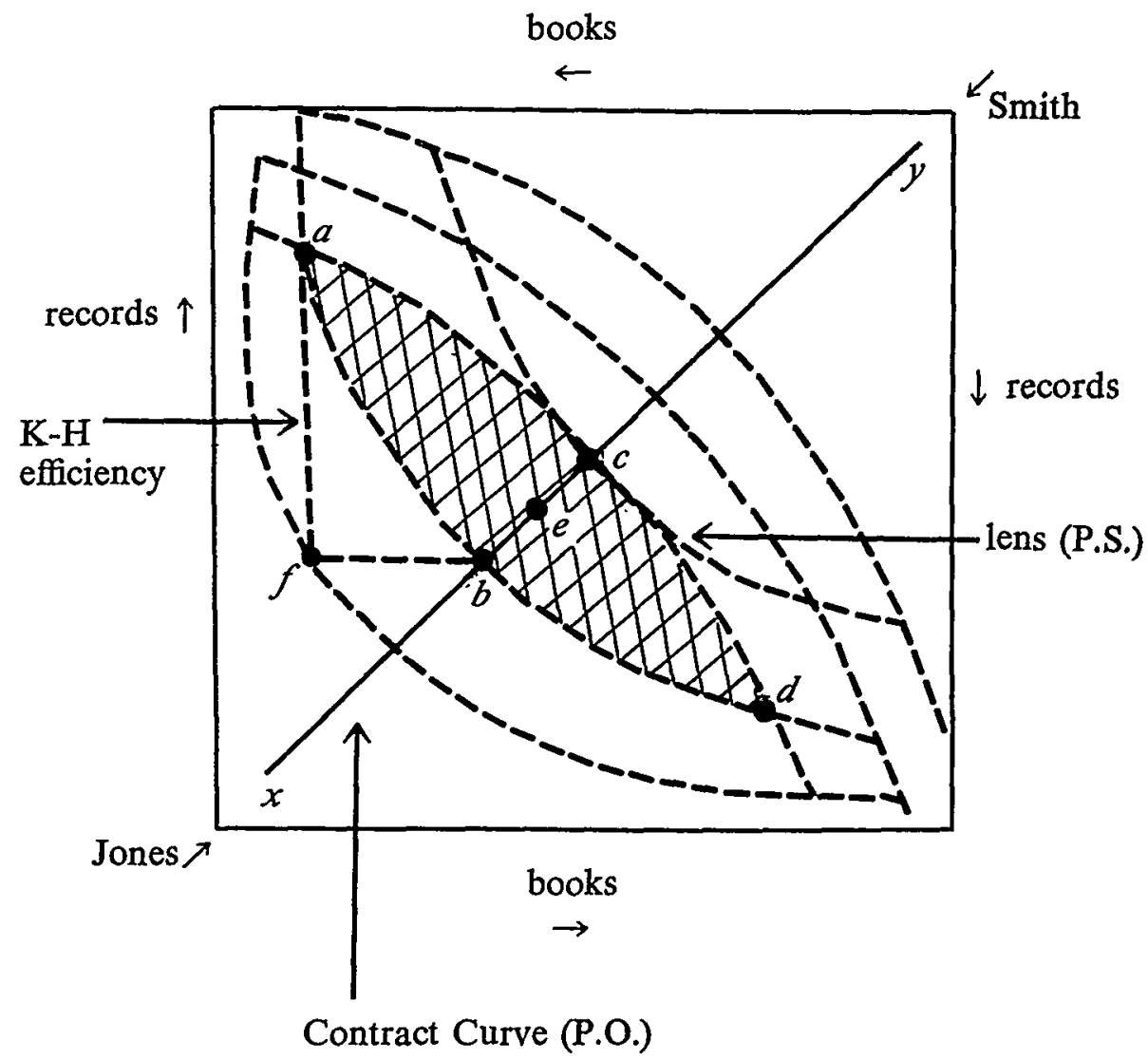

Let $a=$ initial distribution of all records and books between Jones and Sinith. 
(1) The line drawn through $a, b$, and $d$ represents Jones' indifference curve with respect to records and books.

(2) The line drawn through $a, c$, and $d$ represents Smith's indifference curve with respect to the same resources. (The slope of the respective indifference curves is given by the respective marginal rates of substitution of books and records.)

(3) A move from $a$ to $b$ is Pareto superior because Jones is no worse off ( $b$ is on his indifference curve), while Smith is better off ( $b$ is further out from his origm).

(4) A move from $a$ to $c$ is also Pareto superior, this time because it makes Jones better off while Smith is no worse off.

(5) A inove froin $a$ to $e$ is Pareto superior by making both Smith and Jones better off.

(6) The sliaded area formed by the intersection of indifference curves drawn through $a$ is the lens; it represents all possible Pareto superior moves from $a$.

(7) The tangents of indifference curves each represent Pareto optimal distributions.

(8) The line $x, y$ drawn through these points is the contract curve. (Not every Pareto optimal distribution, however, corresponds to a point on the contract curve. ${ }^{24}$ )

(9) Point $c$ represents a Pareto optimal allocation that is also Pareto superior to $a$.

(10) The inove from $a$ to $f$ is Kaldor-Hicks efficient, since at $f$ Smith could compensate Jones so that Jones would be no worse off than at $b$ and Smith would still be better off (farther from the origin).

There is a close and important relationship between Kaldor-Hicks efficiency and Posner's assignment rule. By assigning the appropriate entitlement to the party who would have purchased it had it not been for transaction or other costs, Posner's principle msures that the entitlement will be secured by a party who would have been able to compensate the loser and still gain by the assignment. So assignments of entitlements according to Posner's "high bidder" rule or "auction rule"25 are Kaldor-Hicks efficient. A Kaldor-Hicks efficient reallocation need not be Pareto efficient; it certainly need not be Pareto supe-

24. There are Pareto optimal distributions that cannot be represented in an Edgeworth box. Such distributions are the optimal resolutions of externality problems. The reason why they cannot be so represented is discussed in Part IV infra.

25. I use the term "auction rule" advisedly. Posner's rule does not actually involve an auction. Instead, his is a rule that assigns entitlements as if they were being auctioned. 
rior. Because Posner's rule does not require that the losing bidder be compensated, it does not guarantee that after the entitlement has been assigned the resulting allocation is Pareto superior. Because the rule is designed to mimic or simulate an efficient market outcome, applying it will theoretically produce a Pareto optimal assignment. Posner's rule then generates outcomes that are both Kaldor-Hicks efficient and Pareto optimal. ${ }^{26}$

Coase's markets, Pigou's taxes, and Posner's property right assignment rule are all means of controlling externalities. Strictly speaking, externality problems cannot be represented in an Edgeworth box. That is because Edgeworth Theory assumes both perfect coinpetition and the absence of externalities. Representing an externality problem in an Edgeworth box would therefore violate a basic assunption necessary for constructing such a box. Still, it might be useful to refer back to the Edgeworth box to understand the relationship between Posner's assignment rule and the various notions of efficiency that the box illustrates. Taking some liberties with Edgeworth analysis, then, it might be said that Posner's rule in effect holds that we should assign entitlements so that the resulting allocation of resources is Kaldor-Hicks efficient as constrained by the requirement that it fall on the contract curve. By not requiring that the party assigned the entitlement compensate the loser of the auction, the rule does not guarantee that the redistribution takes place within the lens.

\section{$\mathrm{V}$}

\section{MiMICKING MARKETS}

\section{A. Auction and Exchange}

Posner's assignment rule does not require that the losing bidders be compensated. One question is, why not? The answer given-i.e., the justification offered for denying that interventions in the market of voluntary exchanges require compensation-depends on whether Posner's principle is seen as more closely allied to Coase (Pareto) or to Kaldor-Hicks. The Coasian and Kaldor-Hicks arguments apply to different sorts of economic problems-a fact few proponents of law and economics seem cognizant of-and provide, therefore, very different justifications for not requiring compensation. In exploring both Coa-

26. Whether the result of an assignment along Posner's lines is Pareto optimal will depend on exactly what entitlement is being assigned. The result will be Pareto optimal, of course, only if the entitlement is to the optimal amount of, for example, pollution or smoke. But then the problem is, how can we determme the optimal level of pollution or smoke? This information problem is compounded by income effects. Both are discussed in J. Coleman \& W. Holahan, Mimicking Markets and Auctioning Entitlements (unpublished essay). 
sian and Kaldor-Hicks arguments for denying compensation this section attempts to raise doubts about both the justification for doing so and the claim that Posner's assignment rule mimics the market in the Coasian sense.

Let us begin by placing the burden of the argument on those who would require compensation. What is the case for compensating losers? Consider a standard auction. Suppose $A$ and $B$ both bid for a Frank Stella painting. $A$ 's bid is higher than $B$ 's and he is awarded the painting. Should $A$, the winner, be forced to compensate $B$, the loser? Surely not. By the saine token, why should the winner of Posner's auction be compelled to compensate the loser(s)?

The answer to this question is complex. Its complexity will unfold as we go along. For now it is enough to note at least two differences between auctionmg a work of art and auctioning entitlements along the lines Posner suggests. First, when $A$ wins the auction for a work of art, he still has to fork over the money. He simply does not receive the art work gratis in return for submitting a high and flattering bid. The winners of Posner's auctions do not pay for their prizes. They win by their bid alone. (This presents a difficult problem regarding the rehabihty of information bids provide.) Secondly, in standard auctions individuals who lose the bidding are not disadvantaged (if we ignore envy or jealousy) by the winner's winning. The art collector's "consuming" the Stella does not disadvantage his rival. The winner wins, but the loser does not really lose. He loses the auction but is not harmed by the result. This is not to suggest that a loser is no worse off than he would have been had he won. Because the loser is forced to accept his second best alternative, he is clearly worse off than he would have been had he won the auction. Still, he need be no worse off than he was prior to the auction. In the language of efficiency this characteristic of auctions might be put as follows: auctions of private goods are Kaldor-Hicks efficient and Pareto superior. They are both Kaldor-Hicks efficient and Pareto superior because they produce no real losers. In contrast, if we auction property rights between pollutors and their neighbors, or between smokers and nonsmokers, then if the smokers or pollutors win the auction, the losers really do lose. When smoke gets in one's eyes it burns. So auctioning property rights to pollute or to smoke on a high bid basis may have the result of worsening the lot of the auction's losers. Moreover, it follows from the fact that Posner's rule is KaldorHicks efficient that the high bidder could have compensated the loser and still gamed by the assignment. Why advance a rule that disadvantages some individuals when not even efficiency requires it? The burden is shifted. Why not compensate?

As suggested above, the justification advanced for denying compensation to losers will ultimately depend on whether one adheres to a 
Kaldor-Hicks or Coasian reading of the auction rule. The prevailing view is that Posner's auction rule derives from Coase's theorem. Against Pigou, Coase argues for the success of private exchange as a vehicle for securing efficiency. But exchange markets sometimes are unavailable or too costly to be efficient. Posner's rule is: where markets fail, mimic them. In other words, where transactions or other costs create market failures, Posner's rule assigns entitlements to produce the result the market, under ideal conditions, would have produced. Since the market, as Coase demonstrates, eventually would have worked to move the entitlement to the party who would have been willing to pay more for it, where markets are too expensive or otherwise unworkable, why not simply assign the entitlement to the high bidder straightaway? This Coasian interpretation of Posner's auction rule raises two closely related questions. First, in what ways and to what extent does the auction rule mimic the market in the Coasian sense? Second, if the auction rule derives from Coase's argument, what are the Coasian-related considerations for failing to compensate losers?

Coase's argument relies on exchange rather than auction markets. The point of Coase's argument is that regardless of the assignment of entitlements, market mechanisms will provide the opportunities for mutual gam through trade, and that this process will result im an efficient allocation of resources. Coase's argument therefore emphasizes not only the efficiency of the result-which admittedly could be secured in any number of nonmarket ways-but also the unique capacity of the market to secure an optimal result by individuals exercising autonomy in an effort to maximize utility through exchanges.

There are significant differences between auction and exchange markets. Exchanges (by rational, well-informed persons) are made only when they are to the advantage of all parties to them. Auctions are not trades; they do not guarantee that all parties to the bidding gain or are at least not disadvantaged by the result. Some auctions-for exaunple, those involving works of art-have the effect of improving the lot of some individuals without worsening the lot of others. Other auctions-for example, those imvolving pollution rights-provide no such guarantees.

The phrase "mimic the market" is ambiguous therefore between auction and exchange markets. Coase's market is an exchange market; Posner's is an auction. The question is, to what extent and in what respects does Posner's auction simulate the outcomes of exchange markets? To answer this question, let us reconsider the rancher/farmer example. In this example we distinguish four states of affairs: $S_{1}$, in which no entitlements have as yet been conferred; $S_{2}$, in which the farmer is assigned the entitlement to prohibit the second cow; $S_{3}$, in 
which the rancher is assigned the entitlement to raise the second cow; and $S_{4}$, in which the rancher purchases the entitlement to raise the second cow from the farmer. (This is the story one would reconstruct in that case in which the value of the second cow exceeds the anticipated crop damage.)

Coase's theorem is that under ideal conditions $S_{3}$ or $S_{4}$ would result, either of which would be Pareto optimal. From the point of view of Pareto optimality, we ought to be indifferent with respect to the two. Posner's principle states simply that where there are high transaction costs, choose $S_{3}$. But $S_{3}$ and $S_{4}$ are not inorally equivalent from the point of view of Pareto superiority; $S_{4}$ but not $S_{3}$ is Pareto superior to $S_{1}$.

Posner's rule implores us to choose $S_{3}$ cases even though there may be Paretian-related reasons for preferring $S_{4}$ cases. To "inimic" the outcome of the market as the notion is employed in Coase's argument, at the very least, Posner's assignment primciple should read:
A.P.': (a) Assign the entitlement to the party who would have purchased it ( $S_{3}$ cases) or
(b) Assign the entitlement to the party who would have purchased it and require that the winner compensate the loser $\left(S_{4}\right.$ cases).

Only indifference between these two disjuncts of A.P.' comes close to mimicking the exchange market. Put another way, Posner's rule comes into play only where exchange markets calmot be established. The best that can be done is an assignment rule that mimics the market. An exchange market can, as Coase shows, reach a Pareto optimal result in one of two ways. If Posner's rule is supposed to mimic the market, it should include reconstructed mappings of these two paths.

A defender of Posner's assignment rule might object that while this is all well and good, the costs of rendering compensation might be too great to apply the second disjunct. The costs of coinpensation, in other words, like the costs of making the transaction in the first place, may exceed the difference between the value the higher and lower bidders place on the entitlement. Requiring compensation inay defeat the purpose of the rule by producing a result that is not Pareto optimal. If an assignment rule is to mimic the market at all, it can duplicate only the efficiency of the outcome. To imsure at least an efficient outcoine, the compensation requirement must be abandoned. The auction rule then is simply the best coinpromise. But is it?

When conjoined with the cost of making compensation, a full compensation rule inay generate an inefficient allocation. Something less than full compensation, however, need not. That is, requiring coinpensation up to that amount which, when added to the cost of coinpen- 
sation, is still less than or equal to the price the higher bidder is willing to pay would be a second best option. The result would be a Pareto optimal allocation that involved a close approximation of a Pareto superior move. Being a hittle disadvantaged is preferable to being signifcantly disadvantaged. Alternatively, the difference between the total cost of compensation and the point at which it becomes inefficient for the high bidder to compensate might be paid by the government. After all, why should the loser be forced to suffer any loss whatsoever in the naine of efficiency?

Arguments against the compensation requirement based on the costs of rendering compensation are inconclusive at best. Moreover, soine sort of counmitment to compensation is required if Posner's auction rule is to duplicate Coase's exchange market. Still, a defender of Posner's rule might argue that the information costs of alternative assignment rules, such as the near-Pareto superior one, are so great as to render them useless. That is, the costs of ascertaining the relevant inforination to determine when compensation is adequate and efficient would be overwhelming, thus makmg such a rule impractical.

The problem of inforination costs is more general. Indeed, criticisins based on inforination costs may be forcefully pressed against Posner's own rule. Posner's rule is to assign the entitlement to the highest bidder, or, more precisely, to the individual who, transactions costs aside, would have purchased it in an exchange market. The information problem is this: how do we gather information regarding the relative willingness of individuals to pay for a particular entitlement? In the absence of a inarket in which a person's willimgness to pay is expressed through trades and bids, the cost of ascertaming willingness to pay would be enormous and the rehiability of that information suspect. If, however, a market exists or may be established to determine willingness to pay, Posner's rule is simply otiose. If a market can be established to reveal relative willingness to pay among interested parties, everything necessary for an exchange market exists and there is no need whatsoever to inake an assignment of entitlements along the lines of Posner's or anyone else's assignment principle.

\section{B. Auctions and Kaldor-Hicks}

As noted earlier, the phrase "mimicking the market" is ambiguous between auction and exchange markets. The previous section considered what the difference anounted to. In addition, there is the question of which aspect of the inarket Posner's rule is intended to mimic or simulate. Under one interpretation, Posner's concept of mimicking the market could only inean producing the efficient outcoine the market would have produced. Alternatively, in denying compensation by mimicking the market Posner's rule may be drawing upon aspects of its 
Kaldor-Hicks heritage. In particular, the denial of compensation in Posner's rule may be justified on the same grounds that Kaldor-Hicks advances for failing to do so. There are in general two kinds of cases in which applying Kaldor-Hicks standards of efficiency rather than Paretian ones are thought to be justified: the first involves entry into and exit fron 1 inarkets; the second involves removal of impedinents to competition.

If $A$ enters $B$ 's market and drives him from business, $A$ is not required to compensate $B$, even though in a perfectly competitive economy $A$ could do so and be in a better position than before. This is the principle of costless entry into the market and it involves the KaldorHicks rather than the Pareto superior standard of efficiency. The justification for this principle is that it encourages weeding out inefficiency. Because Posner's assignment rule is not restricted to cases of entry into markets, the application of Kaldor-Hicks and the consequent failure to provide compensation is generally unwarranted.

Kaldor-Hicks is more often used where impediments to competition are removed and the losers are those who have previously been advantaged by the absence of competition. The justification for applying Kaldor-Hicks is that those inonopolists who have benefited from impediments to competition are not entitled to or do not deserve to be compensated. The fariner and the nonsinoker who lose out in Posner's auctions, however, are not inefficient monopolists; they have not been advantaged by impediments to competition the removal of which would bring thein warranted losses. Nor are the farner and nonsmoker like unsuccessful, i.e., inefficient, competitors in a market. While it is true that entitling either the farmer or the nonsmoker would be inefficient in the sense that there could be a Pareto superior assignment of entitlements, there is no sense prior to the assignment of entitlements in which either could be thought of as resource wasters. Not coinpensating losers on Kaldor-Hicks grounds therefore seeins inappropriate, at least in a wide range of cases in which Posner's auction rule applies.

\section{The Case Against Always Compensating}

Posner's auction rule does not require that losers be compensated. Coasian and Kaldor-Hicks considerations might be brought to bear to justify the auction to the exclusion of the bargain. None of these arguments are sufficiently persuasive to justify an auction rule like Posner's. The question that remains is whether an auction rule that requires coinpensation would always be preferable to the Posner rule that never does. Does it follow, in other words, from the arguments which seem decisive against Posner, that full compensation or its nearest efficient approximation ought in every case to be required? This question is 
very closely related to, but slightly different from, the question whether it is always preferable to pursue a Pareto superior path to a Pareto optimal outcome.

This leads inevitably to considering the question economists and lawyers enamored of the economic approach to law seem to shy away from. And that is, even where it is possible to secure a Pareto optimal outcome via a Pareto superior path, is it always preferable to do so? Consider a case in which doubt about domg so exists.

Suppose the neighboring residents of a polluting inanufacturer outbid a pollutor seeking the right to contmue polluting at his current rate. The neighbor's right to a cutback in pollution forces the manufacturer to reduce output and, in the end, it suffers an economic loss. In a Coasian world, the neighbors would have bought away some of the pollution from the manufacturer and so through mutual gain via trade an efficient result would have been reached. The manufacturer, in this exainple, is disadvantaged by the auction. The loss it suffers could be reduced or eliminated by requiring its neighbors to compensate it. There is, however, a legitimate question here about whether the Pareto superior path to the Pareto optimal outcome is preferable to the Pareto inferior path that application of Posner's rule would bring about. There are numerous other cases of this sort, some in which our intuitions would be firmer, others in which they would be less firm. For exainple, would compensation be preferable if the polluting manufacturer were a monopolist? This is just the sort of case that the KaldorHicks formula was meant to cover. What could make the Pareto superior path inore defensible than the Kaldor-Hicks path in such cases?

These examples suggest that while the Posner rule simply lumps together all sorts of cases in which the justifiability of failing to render compensation differs enormously, the alternative rule of always requiring coinpensation-thereby insuring the Pareto superior path to the Pareto optimal outcome-also lumps together all sorts of cases about which our intuitions regarding the propriety of compensation may differ drastically. The simple point is that no assignment rule or principle for intervening in the market can be defended a priori as abstracted froin the kinds of cases it is intended to cover.

Moreover, these examples denonstrate the related point that every economic notion of efficiency is of derivative and limited use in the public policy arena. Consider the various notions of efficiency and their relation to social choice. First, there can never be a priori arguinents for choosing a Pareto optimal distribution of resources to a nonPareto optimal one. Second, the notion of Kaldor-Hicks efficiency derives froin some deeper noneconomic theory of desert and entitlement. Its application is thought justified, after all, precisely in those cases in which parties who have gained, but did not deserve to gam, from im- 
pediments to competition are demied compensation when the impediments are removed. Finally, even the notion of Pareto superiorityeveryone's "golden boy"-is useless as a basis of pohicy independent of a noneconomic justification of the imitial or primary distribution with which the reallocations are to be compared. That is, whether, in every case, a person should be made no worse off by a redistribution will ultimately depend on his deserts and his rights. Unless we know what a person deserves or is entitled to on grounds other than efficiency, we should remain agnostic about the virtues of reallocations that leave him no worse off than before.

One final point about mimicking the market. The state is sometimes asked to allocate resources through the political process, not because the inarket will be unable to do so efficiently, but because, on other grounds, the market is viewed as inappropriate. The allocation of scarce, life-saving inedical resources, for example, may be best left to nonmarket allocative devices. One problem then with unreflective commitınent to the principle of mimicking the market is that in certain cases it may require the state to step into an area in order to allocate resources as the market (under ideal circumstances) would have when the state is really being asked to allocate resources precisely because the market is viewed as inappropriate.

\section{CONCLUSION}

The purpose of this essay has not been to find fault with Posner's assignment rule in the hopes that doing so imght lead to insights about the construction of a more satisfymg property riglit assignment principle. In the end, I am not sufficiently sympathetic to the econoinic vision of human affairs and social institutions to engage in such a task. Instead, my goal has been to look at aspects and examples of the economic approach to law "froin the inside," not as a critic of the entire enterprise, but as someone trying to work his way through it. This essay does not attempt to rebut all of law and economics. For even if efficiency does not carry the day in matters of social policy, arguments from efficiency must be taken seriously. I hope, however, that this essay has contributed to a deeper appreciation of the himits of the economists' contribution to the design of social and legal institutions. 